\title{
Presence of celiac disease epitopes in modern and old hexaploid wheat varieties: wheat breeding may have contributed to increased prevalence of celiac disease
}

\author{
Hetty C. van den Broeck • Hein C. de Jong • Elma M. J. Salentijn • \\ Liesbeth Dekking • Dirk Bosch • Rob J. Hamer • Ludovicus J. W. J. Gilissen • \\ Ingrid M. van der Meer $\cdot$ Marinus J. M. Smulders
}

Received: 13 April 2010 / Accepted: 25 June 2010 / Published online: 28 July 2010

(c) The Author(s) 2010. This article is published with open access at Springerlink.com

\begin{abstract}
Gluten proteins from wheat can induce celiac disease (CD) in genetically susceptible individuals. Specific gluten peptides can be presented by antigen presenting cells to gluten-sensitive T-cell lymphocytes leading to CD. During the last decades, a significant increase has been observed in the prevalence of $\mathrm{CD}$. This may partly be attributed to an increase in awareness and to improved diagnostic techniques, but increased wheat and gluten consumption is also considered a major cause. To analyze whether wheat breeding contributed to the increase of the prevalence of $\mathrm{CD}$, we have compared the genetic diversity of gluten proteins for the presence of two CD epitopes (Glia- $\alpha 9$ and Glia- $\alpha 20)$ in 36 modern European wheat
\end{abstract}

Communicated by J. Snape.

H. C. van den Broeck $(\varangle) \cdot$ E. M. J. Salentijn · D. Bosch ·

L. J. W. J. Gilissen - I. M. van der Meer - M. J. M. Smulders

Plant Research International, Wageningen UR,

P.O. Box 16, 6700 AA Wageningen, The Netherlands

e-mail: hetty.busink@wur.nl

H. C. de Jong

Limagrain Nederland B.V., P.O. Box 1,

4410 AA Rilland, The Netherlands

L. Dekking

Leiden University Medical Center,

P.O. Box 9600, 2300 RC Leiden, The Netherlands

R. J. Hamer

Laboratory of Food Chemistry, Wageningen UR,

P.O. Box 8129, 6700 EV Wageningen, The Netherlands

Present Address:

L. Dekking

Department of Immunology, Dynomics BV,

Erasmus Medical Centre, P.O. Box 82,

1400 AB Bussum, The Netherlands varieties and in 50 landraces representing the wheat varieties grown up to around a century ago. Glia- $\alpha 9$ is a major (immunodominant) epitope that is recognized by the majority of CD patients. The minor Glia- $\alpha 20$ was included as a technical reference. Overall, the presence of the Glia- $\alpha 9$ epitope was higher in the modern varieties, whereas the presence of the Glia- $\alpha 20$ epitope was lower, as compared to the landraces. This suggests that modern wheat breeding practices may have led to an increased exposure to $\mathrm{CD}$ epitopes. On the other hand, some modern varieties and landraces have been identified that have relatively low contents of both epitopes. Such selected lines may serve as a start to breed wheat for the introduction of 'low CD toxic' as a new breeding trait. Large-scale culture and consumption of such varieties would considerably aid in decreasing the prevalence of CD.

\section{Introduction}

Wheat is the third most produced cereal in the world after maize and rice (http://faostat.fao.org/site/567/default.aspx\# ancor). It is a very important food crop for the daily intake of proteins, vitamins, minerals and fibers in a growing part of the world population (Cummins and Roberts-Thomson 2009). Wheat consumption, and especially the intake of its gluten, is, however, also a major cause of the development of celiac disease (CD). CD is an inflammatory disorder of the small intestine resulting in a wide variety of chronically symptoms (diarrhea, bowel pain, headache, growth retardation, osteoporosis, infertility, lymphoma, etc.) in about $1 \%$ of the wheat consuming world population. The prevalence and the risk of death in undiagnosed CD have increased dramatically during the last 50 years in the United States (Rubio-Tapia et al. 2009). Lohi et al. (2007) described a 
doubling of the prevalence of CD in Finland in the last two decades, which definitely could not be ascribed to improved detection only. In Asia, the prevalence of CD is increasing because of a change toward Western-style diets (Cummins and Roberts-Thomson 2009). Changes in life style (e.g., the increasing exclusion of breast feeding) and the time and amount of the first introduction of wheat containing products in early life can be considered major environmental factors causing this increase (Ventura et al. 1999; Ivarsson et al. 2000; Fasano 2006). Wheat consumption as wheat flour and wheat-based products per capita is high in Europe and the Middle East and increasing in Asia (Rubio-Tapia et al. 2009) and is again increasing in the United States (http://www.ers.usda.gov/AmberWaves/september08/findings/wheatflour.htm). In addition, wheat gluten is increasingly applied as an additive in a wide and growing variety of processed foods and in other products, including medicines (Day et al. 2006; Hlywiak 2008; Maltin et al. 2009; Atchison et al. 2010).

Bread wheat (Triticum aestivum) is an allohexaploid species resulting from natural hybridization between a tetraploid $T$. turgidum (dicoccum) carrying the AB-genome and a wild diploid species Aegilops tauschii carrying the D-genome (Gupta et al. 2008, and references therein). Especially, the introduction of the D-genome improved the bread-making properties (Payne et al. 1981a; Payne 1987; Gupta and MacRitchie 1994; Branlard et al. 2001). Over 100 years ago, breeders started to systematically cross and select bread wheat for higher yields, adaption to climate changes, better bread-making characteristics, and improved disease resistance. Little information is available about the breeding history of landraces on these aspects (Zeven 2000). Breeding has resulted in many thousands of different wheat varieties that are stored in genetic resource centers and breeding company stocks. Modern wheat breeding, focusing on the increase of yield, initially narrowed down the genetic base of its germplasm (Leišová et al. 2007). However, genetic diversity has increased again in the set of varieties released since the 1990s because breeders started to use wild relatives and synthetic wheats for introgression of, among others, disease resistances (Van de Wouw et al. 2010). The net effect was neither a decrease nor an increase of genetic diversity, as measured by neutral genetic markers, over the last century. However, this does not exclude the possibility that diversity in some traits may have been reduced or increased. Notably, for prolamins, landraces can contain many different chemotypes in a single population (Damania et al. 1983), but modern varieties have only a small number of different gene combinations for some of the prolamins (Payne et al. 1981b). This raises the important question about possible breeding-induced differences in the presence of T-cell stimulatory epitopes in modern varieties compared to landraces and older varieties.
In wheat, gluten proteins comprised gliadins and glutenins, which are present in approximately equal amounts and form $80 \%$ of the total storage protein content in the wheat kernel, next to albumins (12\%) and globulins (8\%). The gliadins form a large protein family in which $\alpha / \beta-, \gamma-$, and $\omega$-gliadins can be distinguished (Woychik et al. 1961), whereas the glutenins can be subdivided into low-molecular weight glutenin subunits (LMW-GS) and high-molecular weight glutenin subunits (HMW-GS) (Shewry and Tatham 1999). The high proline and glutamine content makes gluten proteins resistant to complete proteolytic digestion (Hausch et al. 2002; Shan et al. 2002, 2004). Gluten peptides resulting from partial digestion of all gluten protein groups $(\alpha / \beta-, \gamma-, \omega$-gliadins, LMW-GS, and HMWGS) may contain T-cell stimulatory epitopes (Koning 2008; Stepniak et al. 2008), but the epitopes from the $\alpha$-gliadins are considered to have by far the highest clinical relevance with regard to both the adaptive immune response and the innate immune response that lead to the development of CD (Sjöström et al. 1998; Arentz-Hansen et al. 2000a, b, 2002; Anderson et al. 2000; Janatuinen et al. 2002; Vader et al. 2002; Maiuri et al. 2003; Molberg et al. 2003; Schuppan et al. 2003; Qiao et al. 2005; Marti et al. 2005; Camarca et al. 2009).

In the present paper, we use two monoclonal antibodies (mAbs) that were raised against the Glia- $\alpha 9$ and Glia- $\alpha 20$ epitopes (Spaenij-Dekking et al. 2004, 2005; Mitea et al. $2008 \mathrm{~b}$ ) for comparison of the presence of T-cell stimulatory epitopes in gluten protein extracts from different wheat landraces and modern varieties. The Glia- $\alpha 9$ epitope is especially known as a major immunodominant epitope that can be recognized by the majority of $\mathrm{CD}$ patients (Vader et al. 2002; Camarca et al. 2009). The Glia- $\alpha 9$ epitope sequence $(\alpha \mathrm{I})$ is part of the proteolytic-resistant 33-mer in $\alpha$-gliadins that has a strong T-cell stimulatory effect (Shan et al. 2002; Shan et al. 2005). The Glia- $\alpha 20$ epitope, which is used in this study as a technical reference, is a minor epitope that is recognized by a minority of patients. For these epitopes, proper mAbs are available. Unfortunately, not all epitopes can be studied properly with existing antibodies, and the consequence of the shorter epitope recognition site of the mAbs compared to the $\mathrm{T}$ cell recognition site might be over-staining, which would result in overestimation of the toxicity.

Recent research using protein extracts from a limited selection of wheat varieties demonstrated a large variation in immune responses, as measured as epitope-specific T-cell responses or in $\mathrm{mAb}$ binding studies (Molberg et al. 2005; Spaenij-Dekking et al. 2005). In the present study, we set out to compare the occurrence of T-cell stimulatory gluten epitopes of modern European varieties with landraces to determine to what extent breeding might have changed the presence of T-cell stimulatory epitopes in wheat. The 
results will be discussed in view of the question to what extent wheat breeding can contribute to the prevalence of CD.

\section{Materials and methods}

Search for the occurrence of sequences recognized by $\mathrm{mAbs}$ and T-cell epitopes

The frequency of known T-cell stimulatory epitope sequences in deduced $\alpha$-gliadin proteins was analyzed using the expressed sequence tag (EST) sequences obtained from hexaploid varieties Lavett and Baldus as described by Salentijn et al. (2009). The deduced $\alpha$-gliadin sequences were analyzed for the different minimal recognition sequences of mAbs and T-cells for Glia- $\alpha 9$ (QPFPQPQ and PFPQPQLPY, respectively) and Glia- $\alpha 20$ (RPQQPYP and FRPQQPYPQ, respectively) (Spaenij-Dekking et al. 2004, 2005; Mitea et al. 2008a, b). No mismatches were allowed.

\section{Grain samples}

A set of 36 modern hexaploid wheat varieties, available for the European market, were obtained from Limagrain, Lelystad, The Netherlands. The varieties were selected for maximum Glu-3 and Gli-1 diversity, in the genetic background of the most frequent composition of HMW-GS alleles (Glu-Al: 0 or 1; Glu-Bl: $7+9$; Glu-Dl: $5+10$; Table 1), based on allozyme patterns that are routinely produced for wheat varieties. The set of landraces (Table 2) was obtained from the Centre for Genetic Resources (CGN), the Netherlands (http://www.cgn.wur.nl/ uk/), except for accession RICP01C0203330, which was obtained from the Research Institute of Crop Production (RICP), Czech Republic. The accessions were selected based on collection period and diversity of geographic origin.

\section{Gluten protein extraction}

For extraction of gluten proteins from wheat, we used the method as described by Van den Broeck et al. (2009a), which combines three sequentially obtained extracts to extract nearly all gliadins and glutenins. Extraction of the residue left after the third extract with $25 \mathrm{mM}$ Tris/ $\mathrm{HCl}(\mathrm{pH}$ 8.0) containing $2 \%$ SDS and with $25 \mathrm{mM}$ Tris/ $\mathrm{HCl}(\mathrm{pH}$ 8.0) containing $2 \%$ SDS and $1 \%$ DTT showed that only some HMW-GS and probably some omega-gliadins/D-type LMW-GS were still present in the sample. The gluten extracts analyzed in this study, therefore, contained most of the gluten proteins present.
Wheat grains were ground in an analytical mill (A 11 Basic, IKA-Werke) and sieved through mesh $(0.5 \mathrm{~mm})$. Gluten proteins were extracted from $50 \mathrm{mg}$ wheat flour by addition of $0.5 \mathrm{ml}$ of $50 \%$ aqueous iso-propanol with continuous mixing (MS1 Minishaker, IKA Works, Inc.) at $1,000 \mathrm{rpm}$ for $30 \mathrm{~min}$ at room temperature, followed by centrifugation at $10,000 \mathrm{rpm}$ for $10 \mathrm{~min}$ at room temperature. The residue was re-extracted twice with $50 \%$ aqueous iso-propanol/1\% DTT/50 mM Tris- $\mathrm{HCl}$, $\mathrm{pH} 7.5$, for $30 \mathrm{~min}$ at $60^{\circ} \mathrm{C}$ with mixing every $5-10 \mathrm{~min}$ followed by centrifugation at $10,000 \mathrm{rpm}$ for $10 \mathrm{~min}$ at room temperature. After addition of each next extraction solution, the residue was resuspended by shaking in a Fastprep ${ }^{\circledR}$ FP220A Instrument for $10 \mathrm{~s}$ at speed $6.5 \mathrm{~m} / \mathrm{s}$ followed by sonification for $10 \mathrm{~min}$ in an ultrasonic bath (Branson 3510, Branson Ultrasonics Corporation). The three obtained supernatants were combined and considered the gluten protein extract. The protein content was quantified using Biorad Protein Assay (Bio-Rad Laboratories), based on the Bradford dye-binding procedure, according to manufacturer's instruction.

\section{SDS-PAGE and immunoblotting}

Equal amounts of gluten proteins were loaded and were separated on SDS-PAGE gels (10\%) (Laemmli 1970) using a Hoefer SE 260 mighty small II system (GE Healthcare). Proteins were blotted onto nitrocellulose (0.2 $\mu \mathrm{m}$, Bio-Rad Laboratories), omitting methanol from the blotting buffer, using a Mini Trans-Blot Cell (BioRad Laboratories) at $100 \mathrm{~V}$ for $1 \mathrm{~h}$. Blots were incubated as described by Cordewener et al. (1995) using mAbs specific for T-cell stimulatory epitopes Glia- $\alpha 9$ (Mitea et al. 2008b), Glia- $\alpha 20$ (Mitea et al. 2008a, b), Glt-156 (LMW-1 and LMW-2) (Spaenij-Dekking et al. 2005; Mitea et al. 2008b), and HMW-glt (Spaenij-Dekking et al. 2004; Mitea et al. 2008b). Antibody binding to the blots was visualized by staining for alkaline phosphataseconjugated secondary antibody, using Nitro Blue tetrazolium (NBT) and 5-bromo-4-chloro-3-indolyl phosphate (BCIP) (Sigma). The gluten protein extract of 'Toronto' was used on each separate immunoblot as an 'inter-gel' control.

Blots were scanned using a Bio-Rad GS-710 Calibrated Imaging Densitometer (Bio-Rad Laboratories) and saved as TIFF images. Pixel intensities were calculated per lane using Quantity One software (Bio-Rad Laboratories). Relative intensities differed specifically per mAb used, but were normalized to values obtained for the 'inter-gel' control. Intensities per lane were categorized into three classes: low $(+)$, medium $(++)$, and high $(+++)$ according to linear subdivision of the maximum intensities. 
Table 1 Details of modern wheat varieties

\begin{tabular}{|c|c|c|c|c|c|c|c|c|}
\hline & Variety & Type & $\begin{array}{l}\text { Quality } \\
\text { group }\end{array}$ & Glu-1 & Glu-3 & Gli-1 & $\begin{array}{l}\text { Year } \\
\text { of release }\end{array}$ & $\begin{array}{l}\text { Country } \\
\text { of origin }\end{array}$ \\
\hline 1 & Kornett & $\mathrm{W}$ & A & $0,7+9,5+10$ & $\mathrm{f}, \mathrm{g}, \mathrm{c}$ & $\mathrm{f}, \mathrm{f}, \mathrm{b}$ & 1997 & Germany \\
\hline 2 & Eta & $\mathrm{S}$ & B & $1,7+9,5+10$ & $\mathrm{f}, \mathrm{f}, \mathrm{c}$ & $\mathrm{f}, \mathrm{g}, \mathrm{b}$ & 1986 & Poland \\
\hline 3 & Thasos & $\mathrm{S}$ & $\mathrm{E}$ & $1,7+9,5+10$ & $\mathrm{f}, \mathrm{f}, \mathrm{c}$ & $\mathrm{a}, \mathrm{f}, \mathrm{g}$ & 1994 & Germany \\
\hline 4 & Triso & $\mathrm{S}$ & $\mathrm{E}$ & $1,7+9,5+10$ & $\mathrm{f}, \mathrm{c}, \mathrm{c}$ & $f, f, b$ & 1996 & Germany \\
\hline 5 & Star & $\mathrm{S}$ & A & $0,7+9,5+10$ & $\mathrm{f}, \mathrm{c}, \mathrm{c}$ & $\mathrm{a}, \mathrm{f}, \mathrm{g}$ & 1986 & Germany \\
\hline 6 & Ramiro & W & A & $1,7+9,5+10$ & $\mathrm{f}, \mathrm{c}, \mathrm{a}$ & $f, b, g$ & 1969 & Germany \\
\hline 7 & Bovictus & W & B & $0,7+9,5+10$ & $e, j, c$ & $\mathrm{~b}, 1, \mathrm{~b}$ & 1993 & Germany \\
\hline 8 & Combi & $\mathrm{S}$ & $\mathrm{E}$ & $0,7+9,5+10$ & $e, g, c$ & $\mathrm{f}, \mathrm{f}, \mathrm{l}$ & 1990 & Germany \\
\hline 9 & Zentos & W & $\mathrm{E}$ & $0,7+9,5+10$ & $\mathrm{e}, \mathrm{g}, \mathrm{c}$ & $\mathrm{a}, \mathrm{f}, \mathrm{g}$ & 1989 & Germany \\
\hline 10 & Naxos & $\mathrm{S}$ & A & $1,7+9,5+10$ & $e, g, c$ & $\mathrm{a}, \mathrm{c}, \mathrm{a}$ & 1992 & Germany \\
\hline 11 & Astron & W & A & $0,7+9,5+10$ & $\mathrm{~d}, \mathrm{~g}, \mathrm{c}$ & $\mathrm{o}, \mathrm{f}, \mathrm{b}$ & 1989 & Germany \\
\hline 12 & Belisar & W & A & $0,7+9,5+10$ & $\mathrm{~d}, \mathrm{~g}, \mathrm{c}$ & $\mathrm{o}, \mathrm{e}, \mathrm{a}$ & 1995 & Germany \\
\hline 13 & Glockner & W & $\mathrm{E}$ & $0,7+9,5+10$ & $\mathrm{~d}, \mathrm{~g}, \mathrm{c}$ & $1, b, b$ & 1993 & Germany \\
\hline 14 & Sperber & W & A & $0,7+9,5+10$ & $\mathrm{~d}, \mathrm{~g}, \mathrm{c}$ & $\mathrm{a}, \mathrm{h}, \mathrm{d}$ & 1982 & Germany \\
\hline 15 & Rektor & W & $\mathrm{E}$ & $1,7+9,5+10$ & $\mathrm{~d}, \mathrm{~g}, \mathrm{c}$ & $\mathrm{a}, \mathrm{f}, \mathrm{a}$ & 1980 & Germany \\
\hline 16 & Tinos & $\mathrm{S}$ & $\mathrm{E}$ & $1,7+9,5+10$ & $\mathrm{~d}, \mathrm{f}, \mathrm{c}$ & $\mathrm{a}, \mathrm{f}, \mathrm{g}$ & 1993 & Germany \\
\hline 17 & Trakos & W & B & $0,7+9,5+10$ & $\mathrm{~d}, \mathrm{c}, \mathrm{c}$ & $\mathrm{b}, \mathrm{f}, \mathrm{b}$ & 1997 & Germany \\
\hline 18 & Toronto & W & A & $0,7+9,5+10$ & $\mathrm{a}, \mathrm{j}, \mathrm{c}$ & $\mathrm{b}, 1, \mathrm{~b}$ & 1990 & Germany \\
\hline 19 & Tambor & $\mathrm{W}$ & A & $0,7+9,5+10$ & $\mathrm{a}, \mathrm{h}, \mathrm{c}$ & $\mathrm{b}, \mathrm{f}, \mathrm{b}$ & 1993 & Germany \\
\hline 20 & Aristos & W & A & $0,7+9,5+10$ & $\mathrm{a}, \mathrm{g}, \mathrm{c}$ & $\mathrm{f}, \mathrm{f}, \mathrm{d}$ & 1997 & Germany \\
\hline 21 & Pegassos & W & A & $1,7+9,5+10$ & $\mathrm{a}, \mathrm{g}, \mathrm{c}$ & $\mathrm{f}, \mathrm{f}, \mathrm{a}$ & 1996 & Germany \\
\hline 22 & Bussard & W & $\mathrm{E}$ & $1,7+9,5+10$ & $\mathrm{a}, \mathrm{g}, \mathrm{c}$ & $\mathrm{f}, \mathrm{c}, \mathrm{b}$ & 1990 & Germany \\
\hline 23 & Mikon & W & B & $1,7+9,5+10$ & $\mathrm{a}, \mathrm{g}, \mathrm{c}$ & $\mathrm{f}, \mathrm{b}, \mathrm{l}$ & 1988 & Germany \\
\hline 24 & Winni & W & B & $1,7+9,5+10$ & $\mathrm{a}, \mathrm{g}, \mathrm{c}$ & $\mathrm{b}, \mathrm{f}, \mathrm{d}$ & 1998 & Germany \\
\hline 25 & Klaros & $\mathrm{S}$ & A & $1,7+9,5+10$ & $\mathrm{a}, \mathrm{g}, \mathrm{c}$ & $a, f, b$ & 1995 & Germany \\
\hline 26 & Quattro & $\mathrm{S}$ & A & $1,7+9,5+10$ & $\mathrm{a}, \mathrm{g}, \mathrm{c}$ & $\mathrm{a}, \mathrm{f}, \mathrm{a}$ & 1995 & Germany \\
\hline 27 & Batis & W & A & $1,7+9,5+10$ & $\mathrm{a}, \mathrm{g}, \mathrm{c}$ & $\mathrm{a}, \mathrm{e}, \mathrm{l}$ & 1994 & Germany \\
\hline 28 & Aron & $\mathrm{W}$ & $\mathrm{E}$ & $0,7+9,5+10$ & $\mathrm{a}, \mathrm{g}, \mathrm{c}$ & $\mathrm{a}, \mathrm{e}, \mathrm{i}$ & 1992 & Germany \\
\hline 29 & Munk & $\mathrm{S}$ & A & $0,7+9,5+10$ & $\mathrm{a}, \mathrm{g}, \mathrm{c}$ & $\mathrm{a}, \mathrm{e}, \mathrm{g}$ & 1993 & Germany \\
\hline 30 & Ambras & W & A & $1,7+9,5+10$ & $\mathrm{a}, \mathrm{g}, \mathrm{c}$ & $\mathrm{a}, \mathrm{b}, \mathrm{k}$ & 1990 & Germany \\
\hline 31 & Urban & W & $\mathrm{E}$ & $0,7+9,5+10$ & $\mathrm{a}, \mathrm{g}, \mathrm{c}$ & $a, b, i$ & 1980 & Germany \\
\hline 32 & Ralle & $\mathrm{S}$ & $\mathrm{E}$ & $1,7+9,5+10$ & $\mathrm{a}, \mathrm{c}, \mathrm{c}$ & $a, f, b$ & 1984 & Germany \\
\hline 33 & Bold & W & B & $0,6+8,5+10$ & $\mathrm{~d}, \mathrm{c}, \mathrm{c}$ & $\mathrm{o}, \mathrm{s}, \mathrm{i}$ & 1996 & Germany \\
\hline 34 & Borenos & W & $\mathrm{E}$ & $0,7+9,2+12$ & $\mathrm{a}, \mathrm{d}, \mathrm{a}$ & $\mathrm{f}, \mathrm{h}, \mathrm{g}$ & 1987 & Germany \\
\hline 35 & Dakota & W & B & $1,7+8,2+12$ & $\mathrm{e}, \mathrm{j}, \mathrm{a}$ & $\mathrm{m}, 1, \mathrm{a}$ & 1996 & Germany \\
\hline 36 & Cadenza & $\mathrm{S}$ & B & $0,14+15,5+10$ & $\mathrm{a}, \mathrm{h}, \mathrm{c}$ & $\mathrm{a}, \mathrm{d}, \mathrm{b}$ & 1992 & UK \\
\hline
\end{tabular}

Allele identification for $G l u-1$, Glu-3, and Gli-1 loci is according to Jackson et al. (1996). W is winter wheat. $\mathrm{S}$ is spring wheat. Quality group according to the German classification (German Federal Office for Plant Varieties): E is Elite wheat, A is Quality wheat, and $\mathrm{B}$ is Bread wheat gradient to $1,000 \mathrm{~V}$ in $30 \mathrm{~min}$, gradient to $5,000 \mathrm{~V}$ in $1 \mathrm{~h}$ $20 \mathrm{~min}$, step and hold at 5,000 V until 6,500 Vh. Prior to second dimension, strips were equilibrated for $15 \mathrm{~min}$ in equilibration buffer (6 M urea, 30\% glycerol, $2 \% \mathrm{SDS}$, $50 \mathrm{mM}$ Tris- $\mathrm{HCl}, \mathrm{pH} 8.8$ ) containing $1 \%$ (w/v) DTT, followed by $15 \mathrm{~min}$ in $5 \mathrm{ml}$ equilibration buffer containing $2.5 \%(\mathrm{w} / \mathrm{v})$ iodoacetamide. Separation in the second dimension was performed using SDS-PAGE gels (10\%) and the SE 260 mighty small II system (GE Healthcare). Gels were used for immunoblotting or stained with PageBlue ${ }^{\mathrm{TM}}$ (Fermentas). 
Table 2 Details of landrace accessions

\begin{tabular}{|c|c|c|c|c|c|c|c|}
\hline & Accession no. & Accession name & $\begin{array}{l}\text { T. aestivum } \\
\text { subspecies }\end{array}$ & $\begin{array}{l}\text { Population } \\
\text { type }\end{array}$ & Type & $\begin{array}{l}\text { Collection } \\
\text { date }\end{array}$ & Origin \\
\hline 1 & RICP01C0203330 & Arcade & aestivum & A & $\mathrm{S}$ & & Belgium \\
\hline 2 & CGN19307 & Minaret & aestivum & A & $\mathrm{S}$ & 1982 & The Netherlands \\
\hline 3 & CGN04210 & Weissahr Rotkorn Binkel & compactum & $\mathrm{L}$ & $\mathrm{S}$ & 1951 & Italy \\
\hline 4 & CGN08510 & Hilgendorf & aestivum & A & $\mathrm{S}$ & 1947 & New Zealand \\
\hline 5 & CGN08315 & Rouge de la Gruyere & compactum & $\mathrm{L}$ & $\mathrm{S}$ & & Switzerland \\
\hline 6 & CGN12393 & Sappo & aestivum & A & $\mathrm{S}$ & 1969 & Sweden \\
\hline 7 & CGN19285 & Baldus & aestivum & A & $\mathrm{S}$ & 1990 & The Netherlands \\
\hline 8 & CGN08025 & Sinde & aestivum & $\mathrm{L}$ & $\mathrm{S}$ & $1972 / 1973$ & Ethiopia \\
\hline 9 & CGN10640 & - & compactum & $\mathrm{L}$ & $\mathrm{S}$ & 1974 & Pakistan \\
\hline 10 & CGN05620 & - & aestivum & $\mathrm{L}$ & $\mathrm{W}$ & & Afghanistan \\
\hline 11 & CGN05359 & Alty Agac Mestnaja & aestivum & $\mathrm{L}$ & $\mathrm{W}$ & & Armenia \\
\hline 12 & CGN12271 & Kamtschatka Mestnaja & compactum & $\mathrm{L}$ & $\mathrm{S}$ & 1964 & Armenia \\
\hline 13 & CGN05414 & Chyrda Bugda Mestnaja & aestivum & $\mathrm{L}$ & $\mathrm{W}$ & & Azerbaijan \\
\hline 14 & CGN06118 & Gomborka & aestivum & $\mathrm{L}$ & $\mathrm{S}$ & 1959 & Azerbaijan \\
\hline 15 & CGN08330 & - & compactum & $?$ & $\mathrm{~W}$ & & Azerbaijan \\
\hline 16 & CGN08306 & - & spelta & $\mathrm{L}$ & $\mathrm{S}$ & & Azerbaijan \\
\hline 17 & CGN08309 & - & spelta & $\mathrm{L}$ & $\mathrm{S}$ & & Azerbaijan \\
\hline 18 & CGN05500 & - & aestivum & $\mathrm{L}$ & $\mathrm{W}$ & 1955 & Iran \\
\hline 19 & CGN06440 & Tritaeg 1 & aestivum & $\mathrm{L}$ & $\mathrm{S}$ & 1955 & Iran \\
\hline 20 & CGN08274 & Weisser Kolbenspelz & spelta & $\mathrm{L}$ & $\mathrm{S}$ & & Germany \\
\hline 21 & CGN12269 & Iran $404 c$ & spelta & $\mathrm{L}$ & $\mathrm{S}$ & & Iran \\
\hline 22 & CGN12270 & Iran 416a & spelta & $\mathrm{L}$ & $\mathrm{S}$ & & Iran \\
\hline 23 & CGN04065 & Bagdad & aestivum & $\mathrm{L}$ & $\mathrm{S}$ & 1902 & Iraq \\
\hline 24 & CGN06150 & Humera & aestivum & $\mathrm{L}$ & $\mathrm{S}$ & & Iraq \\
\hline 25 & CGN06162 & Iraqua & aestivum & $\mathrm{L}$ & $\mathrm{S}$ & 1969 & Iraq \\
\hline 26 & CGN08327 & Irak & compactum & $?$ & $\mathrm{~S}$ & 1964 & Iraq \\
\hline 27 & CGN06183 & - & aestivum & $\mathrm{L}$ & $\mathrm{S}$ & 1969 & Israel \\
\hline 28 & CGN04191 & - & compactum & $\mathrm{L}$ & $\mathrm{S}$ & 1967 & Israel \\
\hline 29 & CGN09728 & - & aestivum & $\mathrm{L}$ & $\mathrm{S}$ & 1981 & Pakistan \\
\hline 30 & CGN12071 & - & aestivum & $\mathrm{L}$ & $\mathrm{S}$ & 1976 & Pakistan \\
\hline 31 & CGN10639 & - & compactum & $\mathrm{L}$ & $\mathrm{S}$ & 1974 & Pakistan \\
\hline 32 & CGN11461 & BraunerSpelzAusSchettlenz & spelta & $\mathrm{L}$ & $\mathrm{W}$ & & Germany \\
\hline 33 & CGN04041 & Ak 702 & aestivum & $\mathrm{L}$ & $\mathrm{S}$ & 1963 & Turkey \\
\hline 34 & CGN04267 & Ak Guzluk & aestivum & $\mathrm{L}$ & $\mathrm{W}$ & 1948 & Turkey \\
\hline 35 & CGN05392 & Bolu & aestivum & $\mathrm{L}$ & $\mathrm{W}$ & 1948 & Turkey \\
\hline 36 & CGN10653 & Turk 169 & aestivum & $\mathrm{L}$ & I & & Turkey \\
\hline 37 & CGN04345 & Galickaja & aestivum & $\mathrm{L}$ & $\mathrm{W}$ & & USSR \\
\hline 38 & CGN05541 & Krymka & aestivum & $\mathrm{L}$ & $\mathrm{W}$ & & USSR \\
\hline 39 & CGN06033 & Artemovka/Lutescens 1418 & aestivum & A & $\mathrm{S}$ & 1945 & USSR \\
\hline 40 & CGN04042 & Akagomughi/Akakomugi & aestivum & $\mathrm{L}$ & $\mathrm{S}$ & 1960 & Japan \\
\hline 41 & CGN04275 & Alton, Ghirka winter & aestivum & $\mathrm{L}$ & $\mathrm{W}$ & 1900 & USSR \\
\hline 42 & CGN05465 & Gelderse Ris & aestivum & $\mathrm{L}$ & $\mathrm{W}$ & $<1900$ & The Netherlands \\
\hline 43 & CGN04381 & Lammas Red & aestivum & $\mathrm{L}$ & $\mathrm{W}$ & & UK \\
\hline 44 & CGN04080 & Chiddam & aestivum & $\mathrm{L}$ & $\mathrm{S}$ & 1863 & France \\
\hline 45 & CGN04164 & Noe & aestivum & $\mathrm{L}$ & $\mathrm{S}$ & 1880 & France \\
\hline 46 & CGN04087 & Chul Bidaj; Idaho Hard & aestivum & $\mathrm{L}$ & $\mathrm{S}$ & 1902 & USSR \\
\hline 47 & CGN06361 & Red Fife & aestivum & $\mathrm{L}$ & $\mathrm{S}$ & 1900 & USA \\
\hline 48 & CGN04236 & Pyrothrix 28 & aestivum & A & $\mathrm{S}$ & 1973 & USSR \\
\hline 49 & CGN05640 & Rode Dikkop & aestivum & $\mathrm{L}$ & $\mathrm{W}$ & $<1901$ & The Netherlands \\
\hline 50 & CGN11465 & Spelt van Hoosterhof & spelta & $\mathrm{L}$ & $\mathrm{W}$ & & Belgium \\
\hline
\end{tabular}

Passport details are from CGN, Wageningen, The Netherlands. A is advanced cultivar; $\mathrm{L}$ is landrace/traditional cultivar; $\mathrm{I}$ is intermediate; $\mathrm{S}$ is spring wheat; $\mathrm{W}$ is winter wheat 
Tandem mass spectrometric analysis and data analysis

Protein bands were excised from SDS-PAGE gel and digested with chymotrypsin (Boehringer Mannheim). Digested peptide mixtures were separated and analyzed by electrospray tandem mass spectrometry (LTQ-Orbitrap, Thermo Fisher Scientific) as described by Van Esse et al. (2008). Proteins were identified by automated database searching (OMSSA, http://pubchem.ncbi.nlm.nih.gov/omssa/) against the $T$. aestivum protein sequence database.

\section{Results}

Search for frequency of epitope sequences

Monoclonal Ab staining, which is much easier than T-cell testing, is currently the only way to perform a comparative study such as carried out here for a large number of varieties and landraces. It is currently also the only tool to quantify for $\mathrm{CD}$ epitopes in breeding programs. One worry could be that, as a consequence of the shorter epitope recognition site of the mAb, staining with the mAbs will not reveal all T-cell epitopes present, while other sites may be stained that do not represent complete epitopes.

To evaluate if there is an under- or overestimation of CD epitopes when using mAbs, we analyzed the frequency of minimal recognition sequences of $\mathrm{mAbs}$ and $\mathrm{T}$-cells for Glia- $\alpha 9$ and Glia-20 in deduced $\alpha$-gliadin proteins encoded by EST sequences obtained from hexaploid varieties Lavett and Baldus. The numbers of protein sequences that contain the various sequences recognized by Glia- $\alpha 9$ and Glia- $\alpha 20$ $\mathrm{mAbs}$ and T-cells are shown in Table 3. Sequences obtained from varieties Lavett and Baldus (Salentijn et al. 2009) contained the sequences recognized by either Glia- $\alpha 9$ (mAb and T-cell) or Glia- $\alpha 20$ (mAb and T-cell) or both. Five sequences obtained from the D-genome of 'Baldus' contained the T-cell epitope sequence for Glia- $\alpha 9$ but only three contained the Glia- $\alpha 9 \mathrm{mAb}$ sequence. On the other hand, a single sequence from 'Lavett' (B-genome) and two sequences from 'Baldus' (B-genome) were obtained that contained the Glia- $\alpha 9 \mathrm{mAb}$ sequence but not the corresponding T-cell sequence. The fact that $\alpha$-gliadins encoded by the B-genome do not contain sequences recognized by the Glia- $\alpha 9$ and Glia- $\alpha 20$ T-cells was consistent with the results of Van Herpen et al. (2006).

As we calculated, over $92 \%$ of the found $\mathrm{mAb}$ epitopes were recognized by the corresponding T-cells (Table 3), which means that there is a small overestimation of the $\mathrm{CD}$ epitopes in a cultivar using mAb staining compared to $\mathrm{T}$-cell testing.

To analyze whether $\alpha$-gliadin epitopes are present in other protein than only $\alpha$-gliadins, the NCBI protein data-
Table 3 Search results for Glia- $\alpha 9$ and Glia- $\alpha 20$ epitope sequences present in deduced $\alpha$-gliadin sequences from hexaploid varieties Lavett and Baldus (Salentijn et al. 2009)

\begin{tabular}{|c|c|c|c|c|c|c|c|}
\hline \multirow[t]{2}{*}{ Variety } & \multirow[t]{2}{*}{ Genome } & \multicolumn{2}{|c|}{ Glia- $\alpha 9$} & \multicolumn{2}{|c|}{ Glia- $\alpha 20$} & \multicolumn{2}{|c|}{$\begin{array}{l}\text { Glia- } \alpha 9+ \\
\text { Glia- } \alpha 20\end{array}$} \\
\hline & & $\mathrm{mAb}$ & T-cell & $\mathrm{mAb}$ & T-cell & $\mathrm{mAb}$ & T-cell \\
\hline \multirow[t]{3}{*}{ Lavett } & $\mathrm{A}(n=4)$ & 4 & 4 & 2 & 2 & 2 & 2 \\
\hline & $\mathrm{B}(n=1)$ & 1 & - & - & - & - & - \\
\hline & $\mathrm{D}(n=7)$ & 6 & 6 & 5 & 5 & 5 & 5 \\
\hline \multirow[t]{3}{*}{ Baldus } & $\mathrm{A}(n=2)$ & 2 & 2 & 1 & 1 & 1 & 1 \\
\hline & $\mathrm{B}(n=7)$ & 2 & - & - & - & - & - \\
\hline & $\mathrm{D}(n=5)$ & 3 & 5 & 5 & 5 & 3 & 5 \\
\hline $\begin{array}{l}\text { Total } \\
\qquad(n=26)\end{array}$ & & 18 & 17 & 14 & 13 & 11 & 13 \\
\hline
\end{tabular}

The number in each cell represents the presence of the recognized sequences by $\mathrm{mAb}$ or T-cell. The symbol '-' in a cell means that the sequence was not present

base (http://www.ncbi.nlm.nih.gov/sites/entrez?db=protein) was screened for sequences that could be recognized by the Glia- $\alpha 9$ and Glia- $\alpha 20$ mAbs and T-cells. The search showed that $\gamma$-gliadins and $\omega$-gliadins/D-type LMW-GS exist that contain the Glia- $\alpha 9 \mathrm{mAb}$ recognition sequence, although no corresponding $\mathrm{T}$-cell recognition sequence was present in these $\gamma$-gliadins and $\omega$-gliadins/D-type LMW-GS. For the wheat lines from which the NCBI protein database sequences have been derived, this would lead to overestimation of Glia- $\alpha 9$ epitopes using antibody staining. No $\gamma$-gliadins and $\omega$-gliadins/D-type LMW-GS were found that contain sequences recognized by the Glia- $\alpha 20 \mathrm{mAb}$ or T-cells.

\section{SDS-PAGE and immunoblotting}

The gluten protein content in the grains of 36 modern wheat varieties was on average $24.4 \pm 3.6 \mu \mathrm{g} / \mathrm{mg}$ flour. In grains from landrace accessions, the average gluten protein content was $30.9 \pm 3.4 \mu \mathrm{g} / \mathrm{mg}$ flour. The difference in protein content is most likely caused by the different environments in which the varieties were grown. A higher amount of starch in combination with a stable total amount of protein leads to a reduction of the gluten protein content per $\mathrm{mg}$ of flour.

The wheat varieties and landraces were analyzed by immunoblotting using mAbs against T-cell stimulatory epitopes Glia- $\alpha 9$ and Glia- $\alpha 20$ to detect the number of proteins present containing these epitope sequences. Equal amounts of protein were loaded on the gels.

\section{Modern varieties}

Most modern varieties showed a number of the same (or very comparable) staining patterns for both mAbs 


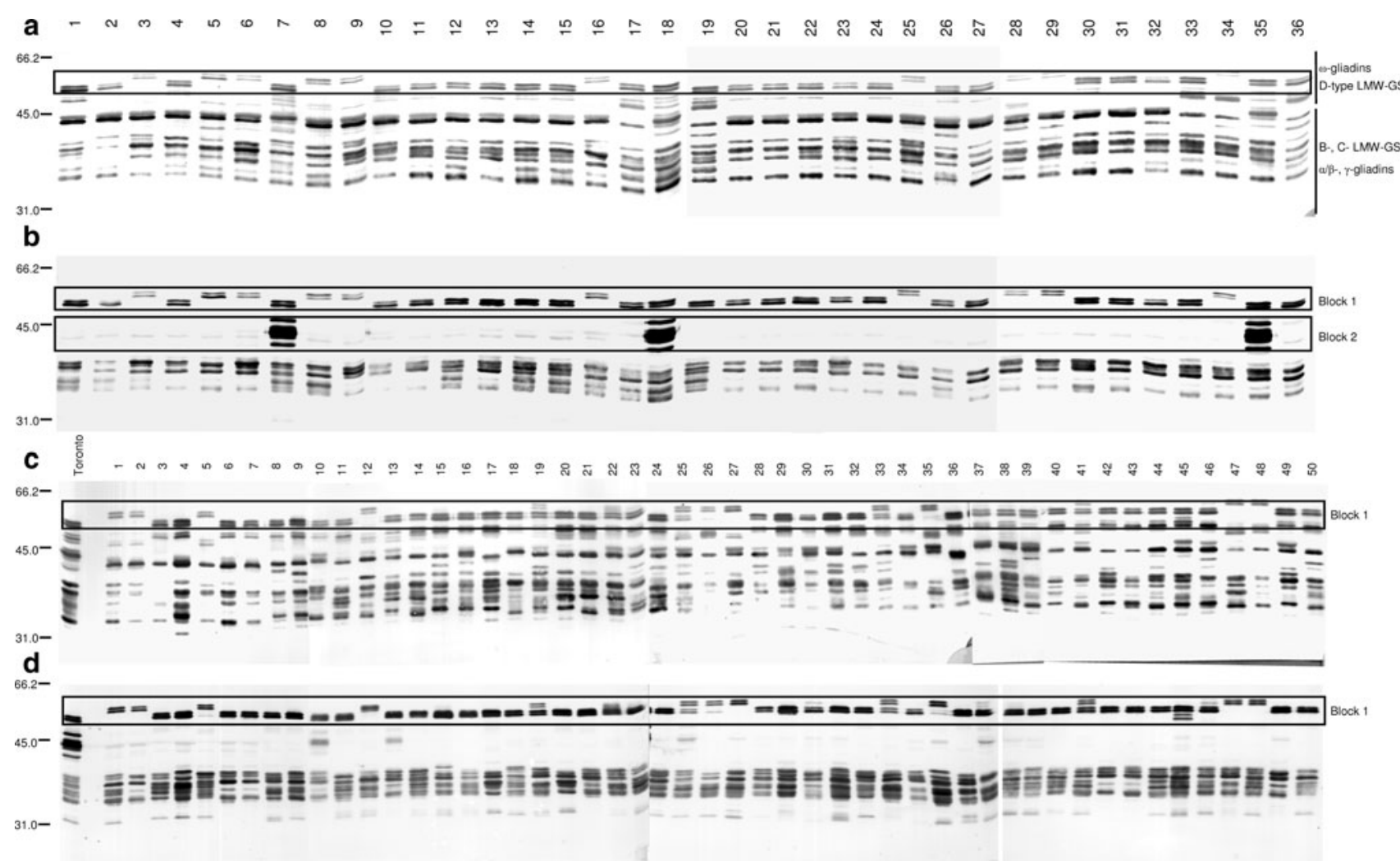

Fig. 1 Analyses of gluten protein extracts from 36 modern wheat varieties and hexaploid landrace accessions. Immunoblots modern varieties using a mAb Glia- $\alpha 9$, b mAb Glia- $\alpha 20$. Immunoblots landraces

against Glia- $\alpha 9$ and Glia- $\alpha 20$ epitopes (Fig. 1a, b), but distinct patterns were obtained for 'Kornett' (Table 1, no. 1), 'Bovictus' (Table 1, no. 7), 'Trakos' (Table 2, no. 17), 'Toronto' (Table 1, no. 18), 'Tambor' (Table 1, no. 19), 'Bold' (Table 1, no. 33), 'Dakota' (Table 1, no. 35), and 'Cadenza' (Table 1, no. 36).

Some distinct blocks of bands were visible that are identical in several cultivars. Using the Glia- $\alpha 20 \mathrm{mAb}$, two closely linked proteins assigned as $\omega$-gliadins/D-type LMW-GS were stained, which we will refer to as 'block-1' proteins (Fig. 1b). The molecular masses of these two linked proteins were $\sim 55 \mathrm{kDa}$. This block occurred in 26 modern wheat varieties. Ten varieties had two proteins of $\sim 60 \mathrm{kDa}$, probably linked $\omega$-gliadins/D-type LMW-GS, which can also be stained with the Glia- $\alpha 9$ mAb (Fig. 1a). The lower one of these two bands from variety Bovictus (Table 1 , no. 7) was characterized by LC-MS/MS and showed $54.6 \%$ protein coverage with a D-type LMW-GS from T. aestivum (CAR82265) and $29.6 \%$ protein coverage with an $\omega$-gliadin from $T$. aestivum (AAG17702) (results not shown). Within those two sequences, no recognition sequence is present for the Glia- $\alpha 20 \mathrm{mAb}$, with which the protein bands gave a clear signal. However, among the peptide sequences that were identified by LC-MS/MS, using c mAb Glia- $\alpha 9$, d mAb Glia- $\alpha 20$. Boxes indicate 'block-1' and 'block-2' proteins

sequences were obtained that carry the Glia- $\alpha 20 \mathrm{mAb}$ and T-cell epitope sequence. Until now, only a few $\omega$-gliadin and D-type LMW-GS proteins have been sequenced because they are difficult to clone due to the presence of large repetitive domains (Hassani et al. 2008). Molecular masses of 1B- and 1D-encoded $\omega$-gliadins are often overestimated by SDS-PAGE compared to mass spectrometry (DuPont et al. 2000). These $\omega$-gliadins are encoded by two closely linked genes on the Gli-Dl locus (Kasarda et al. 1983). From studies on 'Chinese Spring' deletion lines (Van den Broeck et al. 2009b), we know that these proteins are absent in plants in which parts of the short arm of chromosome 1D were deleted. In contrast, no $\omega$-gliadins reacting with $\mathrm{mAb}$ Glia- $\alpha 9$ and Glia- $\alpha 20$ were removed in lines having deletions of the short arms of chromosome $1 \mathrm{~A}$ or 1B. Our epitope staining data support earlier results (Ensari et al. 1998; Denery-Papini et al. 1999; Camarca et al. 2009) showing that $\omega$-gliadins may contain epitopes that are involved in gluten-sensitive response of $\mathrm{CD}$ patients.

When stained by the Glia- $\alpha 20 \mathrm{mAb}$, the three varieties Bovictus (Table 1, no. 7), Toronto (Table 1, no. 18), and Dakota (Table 1, no. 35) showed another block of tentatively linked gluten proteins between 42 and $50 \mathrm{kDa}$ (Fig. 1b, referred to as 'block 2') that were also stained by 
the Glia- $\alpha 9 \mathrm{mAb}$. This indicates that these proteins contained both epitope sequences. The 'block-2' proteins are also detected in immunoblot analyses of CIMMYT synthetic hexaploid wheat lines (results not shown). The proteins are not visible in the tetraploid parent lines and occur independently of the 'block-1' gluten proteins. Hence, they are most likely encoded by chromosome 1D.

The epitope sequence search revealed that deduced $\alpha$-gliadin sequences contained both sequences recognized by the Glia- $\alpha 9 \mathrm{mAb}$ and the Glia- $\alpha 20 \mathrm{mAb}$ (Table 3). The fact that $\alpha$-gliadin sequences can contain sequences recognized by both mAbs is confirmed by the results in Fig. 2, which shows gluten proteins containing either the sequence recognized by the Glia- $\alpha 9 \mathrm{mAb}$, the Glia- $\alpha 20 \mathrm{mAb}$ or both. Overall, most of the $\alpha$-gliadins contain the Glia- $\alpha 9$ epitope and only few, depending on the variety, contain just the Glia- $\alpha 20$ epitope.

Other mAbs that were used in screening were raised against epitopes from HMW-glutenin and LMW-GS (Glt-156). Immunoblotting showed that all HMW-GS present in our modern varieties (a limited set: Glu-Al: 0 or 1; Glu-B1: $7+9$; Glu-D1: $5+10$; Table 1) stained with the $\mathrm{mAb}$ against the HMW-Glt epitope (not shown). This was confirmed by a NCBI database search in which all full-size HMW-GS were shown to contain the HMW epitope. The T-cell epitope from LMW-GS (Glt-156) is covered by two mAbs. Both mAbs were used in screening (data not shown). The mAb covering the $\mathrm{N}$-terminal part as well as the antibody against the C-terminal part of the T-cell epitope resulted in one to three bands appearing on immunoblots of which mostly one, and sometimes two, were overlapping. Both epitopes are not considered major epitopes.

The existing mAbs against Glia- $\gamma 1$, unfortunately, only recognize two amino acids of the T-cell epitope (Mitea et al. 2008b) and were therefore not used for screening for the Glia- $\gamma 1$ epitope, which is the most important of the $\gamma$-gliadin epitopes (Salentijn et al., in prep).

\section{2-DE}

When gluten proteins from 'Bovictus' (Table 1, no 7) and 'Sperber' (Table 1, no. 14) were separated in more detail by 2-DE, a single band on an immunoblot often yielded more than one protein spot (Fig. 3). Because of the complexity of protein bands, care has to be taken in assigning protein bands directly as alleles to varieties, based on one-dimensional SDS-PAGE protein patterns alone.

\section{Landraces}

The results for the landraces showed much more diverse protein patterns for proteins that bind Glia- $\alpha 9$ or Glia- $\alpha 20$
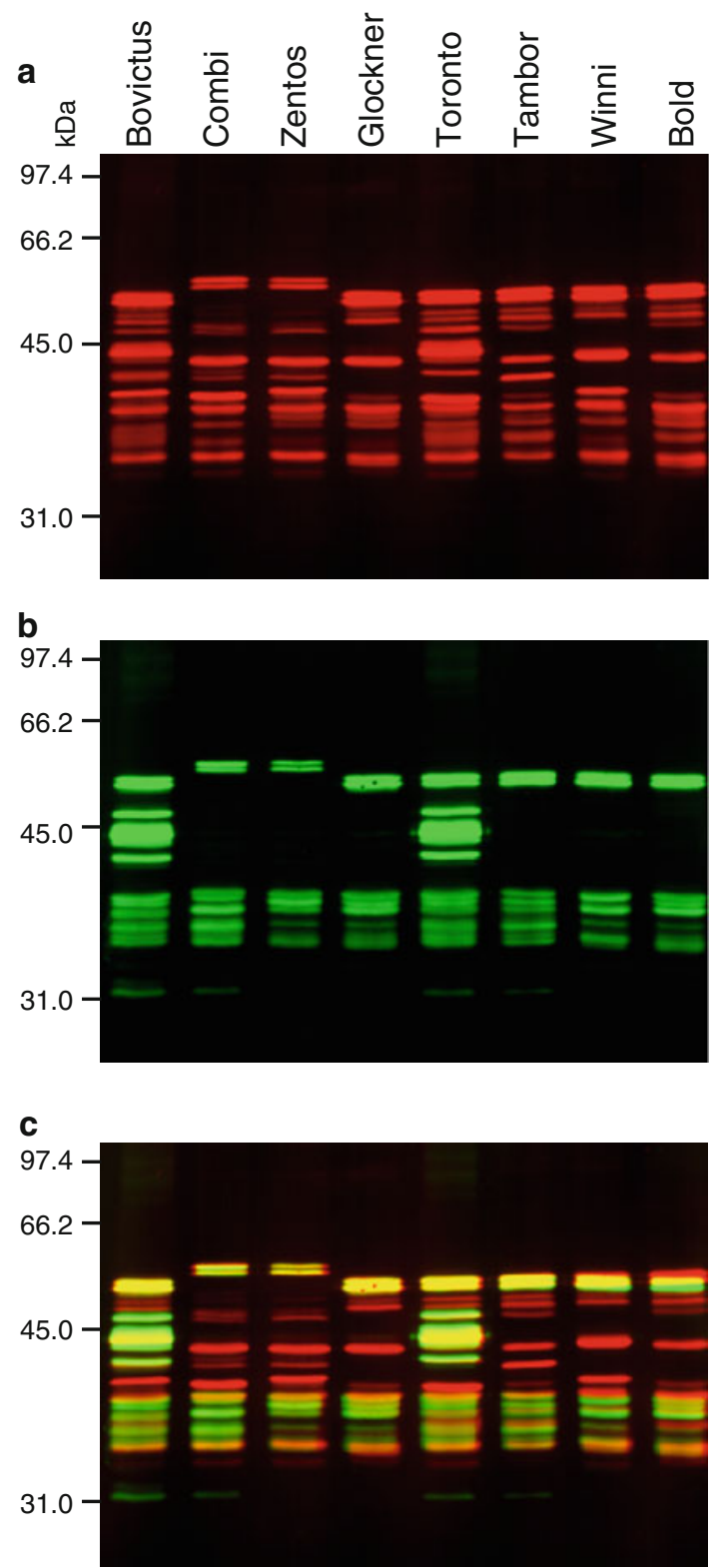

Fig. 2 Images represent immunoblot results for modern wheat varieties Bovictus, Combi, Zentos, Glockner, Toronto, Tambor, Winni, and Bold. a Red channel shows the results with mAb Glia- $\alpha 9$. b Green channel for results with mAb Glia- $\alpha 20$. $\mathbf{c}$ Overlay of both images in (a) and (b). In yellow, identical gluten protein bands are shown

mAb (Fig. 4a, b). The two closely linked $\omega$-gliadins/D-type LMW-GS were also present in the landraces (boxed proteins in Fig. 1c, d). In some landraces, both the higher and lower molecular mass $\omega$-gliadins/D-type LMW-GS were present. This may be caused by genetic heterogeneity within the accessions that were obtained from a Genebank, since several kernels were combined for protein extraction. The 'block-2' gluten proteins were not found in any of the landraces we have tested. 
Fig. 3 2-DE analysis of the gluten protein extracts from modern wheat varieties Bovictus and Sperber. a 2-DE gel of

'Bovictus' stained with PageBlue. b Immunoblot of 'Bovictus' using mAb Glia- $\alpha$ 9. c Immunoblot of 'Bovictus' using mAb Glia- $\alpha 20$.

d Immunoblot of 'Sperber' using $\mathrm{mAb}$ Glia- $\alpha 20$. Lanes at the left in (b), (c), and (d) are one-dimensional immunoblots. Boxes indicate 'block-1' and 'block-2' proteins
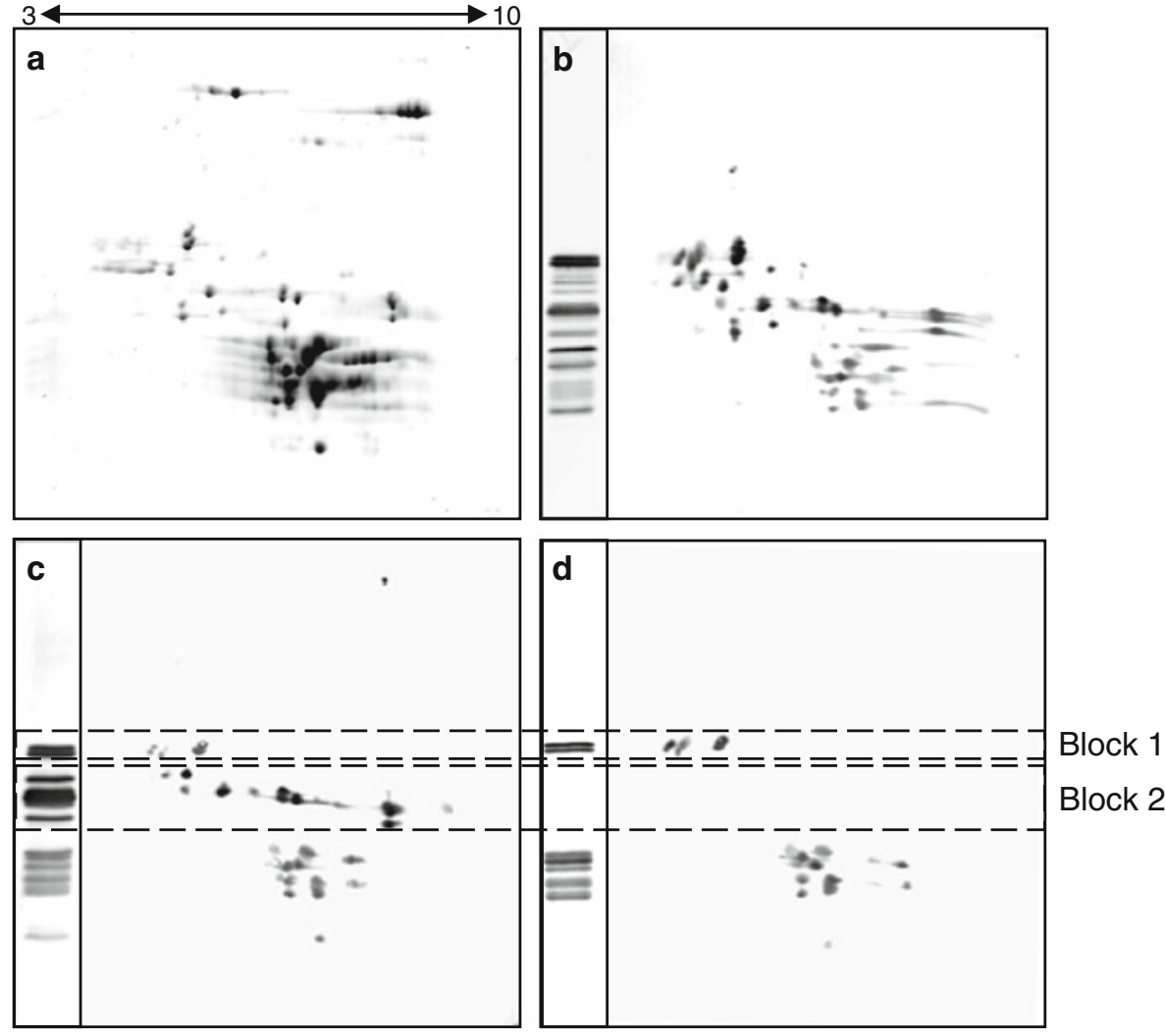
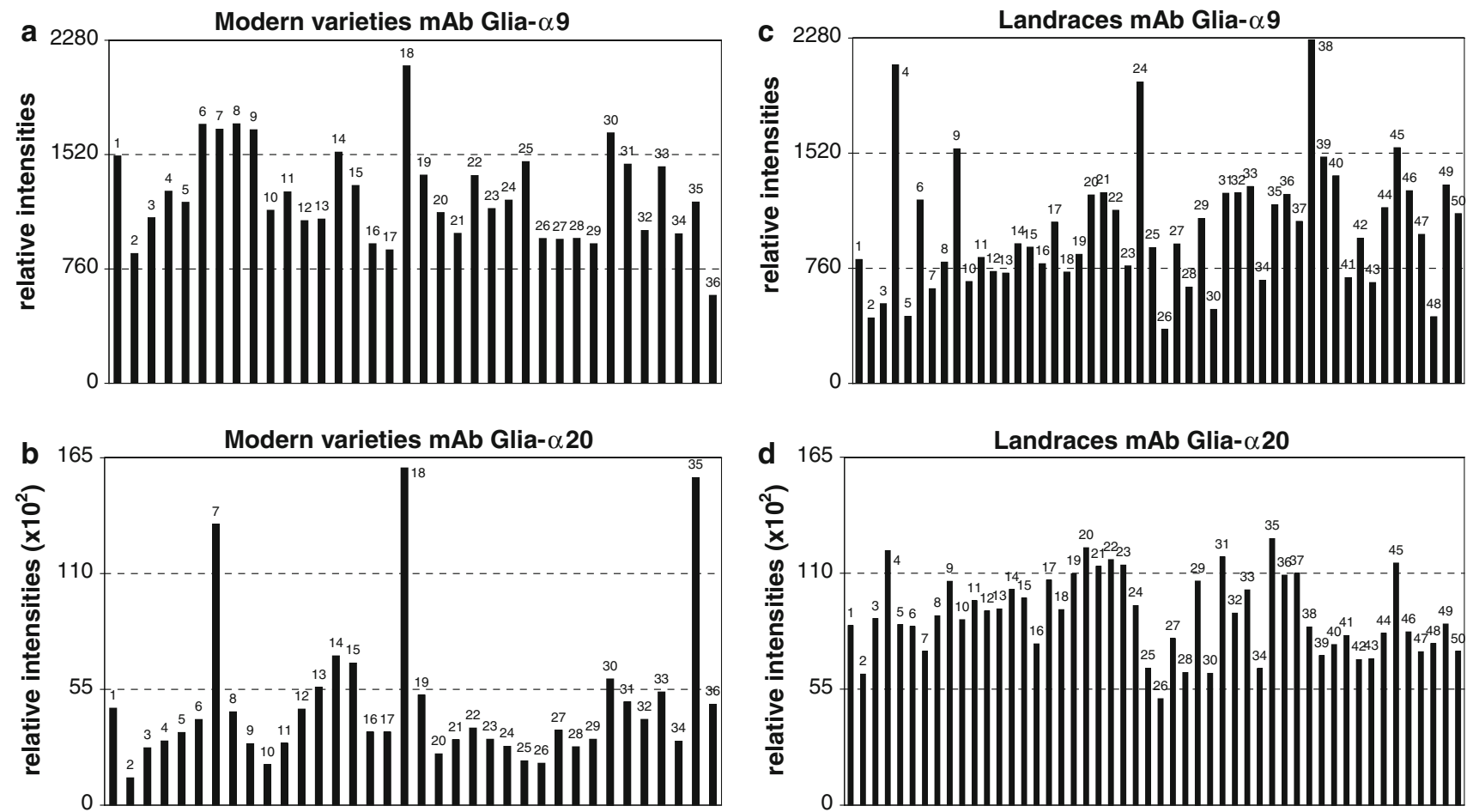

Fig. 4 Immunoblots from Fig. 1 were scanned and the relative intensities are shown for mAbs Glia- $\alpha 9$ and Glia- $\alpha 20$. a Glia- $\alpha 9$ in modern wheat varieties, b Glia- $\alpha 20$ in modern wheat varieties, $\mathbf{c}$ Glia- $\alpha 9$ in wheat landraces, and d Glia- $\alpha 20$ in wheat landraces 
Immunoblot intensities

Immunoblots were scanned from Figs. 1a, b, c, and d and the pixel intensity of each lane was calculated. Our results indicate that $\omega$-gliadins/D-type LMW-GS may contain T-cell stimulatory epitopes Glia- $\alpha 9$ and Glia- $\alpha 20$. For this reason, these bands have been included in the pixel intensity measurements of the variety and landrace gel lanes to quantify the overall intensity as presented in Fig. 4. In addition, also signals caused by response of $\gamma$-gliadins to the Glia- $\alpha 9$ $\mathrm{mAb}$ have been included in the intensity measurements. Although we did not find an intact epitope in our database analysis, the set of $\gamma$-gliadin sequences present in the NCBI database might be too limited to exclude the possibility of the presence of the Glia- $\alpha 9$ T-cell epitope. We sorted the intensities for both mAb stainings in three classes: low (+), medium (++), or high (+++) (Fig. 4). Clear differences in the immunoblot staining of Glia- $\alpha 9$ and Glia- $\alpha 20$ epitopes were found among and between varieties and landraces as groups. The calculation of relative intensities is used to measure the level of $\mathrm{CD}$ epitopes in the different wheat samples. It is, at the moment, the most accurate way to compare the presence and levels of CD epitopes in wheat, as it takes into account the fact that there are differences in relative expression levels and that some gluten proteins may contain multiple copies of an epitope. Furthermore, it does not rely on the daunting task of fully separating all gluten protein variants into individual spots on a 2-DE gel.

From the modern varieties, Cadenza (Table 1, no. 36) showed the lowest response to both mAbs. Among the landraces, CGN08327 (Table 2, no. 26) showed the lowest response to both mAbs. Other landraces showing low response to the Glia- $\alpha 9$ mAb (but medium to the Glia- $\alpha 20$ mAb) are 'Minaret' (CGN19307, Table 2, no. 2, advanced cultivar), 'Weissahr Rotkorn Binkel' (CGN04210, Table 2, no. 3), 'Rouge de la Gruyere' (CGN08315, Table 2, no. 5), CGN12071 (Table 2, no. 30), and 'Pyrothrix 28' (CGN04236, Table 2, no. 48, advanced cultivar).

No systematic differences were observed between spring and winter wheat varieties based on the relative intensities for both mAbs. Among the landraces, the accessions classified as subspecies compactum and spelta did not differ systematically from the others. In addition, landraces could not be grouped according to their country or region of origin. This may be partly due to because of the fact that the recorded country is the country of the first Genebank collection, which often may not be the country where it originated from.

\section{Discussion}

Looking back over the last five decades, several trends are apparent in wheat consumption: an increase in wheat consumption per capita (Rubio-Tapia et al. 2009) (http://www. ers.usda.gov/AmberWaves/september08/findings/wheatflour. $\mathrm{htm}$ ), an increase in CD-related T-cell stimulatory epitopes in wheat (as for the major epitope Glia- $\alpha 9$, this paper), an increase in the use of gluten in food processing (Day et al. 2006; Atchison et al. 2010), and an increase in the consumption of processed foods. To some extent this can be attributed to an increase in awareness and improved diagnostic techniques. Given the relation between incidence of $\mathrm{CD}$ and exposure to cereals, it cannot be ruled out that an increased content of T-cell stimulatory epitopes has also contributed to this increased prevalence.

A diet based on wheat varieties reduced in T-cell stimulatory epitopes may help in the prevention of $\mathrm{CD}$, as it has been observed that the amount and duration to gluten exposure are associated with the initiation of CD (Ventura et al. 1999; Ivarsson et al. 2000; Fasano 2006). Wheat gluten proteins determine the elasticity and viscosity of the dough (Shewry and Tatham 1997; Branlard et al. 2001), but they also showed to be highly useful in food processing. Gluten is widely applied in the production of soups, sauces, meat products, potato chips, candies, ice creams, and even in medicines, vitamin supplements, etc. Wheat varieties with very low amounts of T-cell stimulatory epitopes may be tolerated by many CD patients (Janatuinen et al. 2002; Vader et al. 2003). The reduction of the amount of major T-cell stimulatory epitopes in food will especially benefit children, in which the onset of CD may be delayed or even prevented, and in non-diagnosed $\mathrm{CD}$ patients (the vast majority of all CD patients) to strongly reduce their symptoms. This means that breeding for wheat with considerably reduced T-cell stimulatory epitopes is to be considered as a serious option.

This study explored differences in the presence of T-cell stimulatory gluten epitopes between modern wheat varieties and landraces, aiming at breeding strategies for the reduction of T-cell stimulatory epitopes in gluten-containing food products. Immunoblotting was used to compare 36 modern wheat varieties and 50 landraces. Monoclonal Abs specific for the T-cell stimulatory epitopes Glia- $\alpha 9$ and Glia- $\alpha 20$ were used. We found that the diversity in banding patterns was lower in the modern varieties, clearly indicating a reduced genetic diversity. This implies that non-diagnosed CD patients nowadays may encounter a less diverse set of gluten proteins than several decades ago. The set of landraces included accessions from all over the world and the modern varieties are all European varieties. This does not affect the comparison as the decrease in diversity of $\alpha$-gliadins in varieties is the same when only landraces of European origin are considered.

So, can wheat breeding successfully be used to lower exposure to T-cell stimulatory epitopes? In the set of wheat varieties studied, we found a number of candidates that 
exhibit a low content of the epitopes measured. Among the 36 modern varieties, only one variety was identified with a low response against the Glia- $\alpha 9 \mathrm{mAb}$ (the immunodominant epitope), compared to 15 out of 50 landraces, whereas the frequencies of high responders to this antibody were almost the same. The opposite was found regarding the Glia- $\alpha 20 \mathrm{mAb}$, which showed a significantly higher overall antibody response in the landraces. Considering the epitope impact on CD patients of the major immunodominant Glia- $\alpha 9$ epitope, it is concluded from these data that in general the toxicity of modern wheat varieties has increased.

Landraces will require further breeding to increase their agronomical and food-technological value. On the other hand, with a worldwide occurrence of $1 \%$ of $\mathrm{CD}$ patients and a high frequency (85-90\%) of undiagnosed individuals, some agronomic drawbacks may be acceptable.

Monoclonal $\mathrm{Ab}$ staining is a less time-consuming and much easier method to screen a large number of varieties for the presence of T-cell stimulatory epitopes than dealing with T-cell clones, but requires specific mAbs. These are available for a subset of all epitopes that have been identified in wheat. As Glia- $\alpha 9$ is a major T-cell epitope from $\alpha$-gliadins which is recognized by most patients (Vader et al. 2002; Camarca et al. 2009), we have used it here as a proxy for CD toxicity of all $\alpha$-gliadin. The $\gamma$-gliadins also contain various T-cell epitopes that are recognized by groups of patients, although by fewer patients than the $\alpha$-gliadins. Unfortunately, there are no specific mAbs against $\gamma$-gliadin epitopes that recognize any of these T-cell stimulatory epitopes reliably. New methods are currently being developed, using high throughput sequencing of transcripts and proteomics of gluten proteins. Hopefully, it will become possible to qualitatively and quantitatively assess the presence of all CD T-cell stimulatory epitopes in wheat varieties. To prove, however, that wheat varieties can be considered safe for consumption by $\mathrm{CD}$ patients, we will need $\mathrm{T}$-cell testing using T-cells from a large number of patients and, ultimately, a trial in which $C D$ patients will be challenged by hopefully non-CD-stimulatory wheat varieties.

\section{Conclusion}

It stands to reason that reduction of T-cell stimulatory epitopes in wheat may directly contribute to increasing the quality of life of many individuals. Further selection of varieties and landraces low in T-cell stimulatory $\alpha$-gliadin epitopes and other major epitopes (e.g. from $\gamma$-gliadins) can be considered a responsibility of wheat breeding companies together with research organizations and government. Starting from such selections of 'low in CD epitopes' wheat, 'low in CD epitopes gluten' may become an important new trait in wheat breeding. The inclusion in breeding programs of varieties from different origins will assure the maintenance of a broad genetic diversity. Such selection strategies should also include the use of tetraploid (durum) and diploid wheat species. Further application of advanced breeding technologies, including re-synthesizing of hexaploids and specific gene silencing, will additionally be helpful.

Acknowledgments The authors would like to thank Oscar Vorst (Plant Research International) and Noor Bas (Centre for Genetic Resources, The Netherlands (CGN) for assisting in making the selection of modern wheat varieties and the landrace accessions. Thanks to Sjef Boeren (Wageningen University) for support with LC-MS/MS analysis. This research was funded by the Celiac Disease Consortium, an Innovative Cluster approved by the Netherlands Genomics Initiative and partially funded by the Dutch Government (BSIK03009), and by the Dutch Ministry of Agriculture, Nature, and Food Quality of The Netherlands through the DLO program 'Plant and Animal for Human Health' (project KB-05-001-019-PRI).

Open Access This article is distributed under the terms of the Creative Commons Attribution Noncommercial License which permits any noncommercial use, distribution, and reproduction in any medium, provided the original author(s) and source are credited.

\section{References}

Anderson RP, Degano P, Godkin AJ, Jewell DP, Hill AVS (2000) In vivo antigen challenge in celiac disease identifies a single transglutaminase-modified peptide as the dominant $\alpha$-gliadin T-cell epitope. Nat Med 6:337-342

Arentz-Hansen EH, McAdam SN, Molberg Ø, Kristiansen C, Sollid LM (2000a) Production of a panel of recombinant gliadins for the characterisation of $\mathrm{T}$ cell reactivity in coeliac disease. Gut 46:46-51

Arentz-Hansen H, Korner R, Molberg Ø, Quarsten H, Vader W, Kooy YMC, Lundin KEA, Koning F, Roepstorff P, Sollid LM, McAdam SN (2000b) The intestinal T-cell response to $\alpha$-gliadin in adult celiac disease is focused on a single deamidated glutamine targeted by tissue transglutaminase. J Exp Med 191:603-612

Arentz-Hansen H, McAdam SN, Molberg Ø, Fleckenstein B, Lundin KEA, Jorgensen TJD, Jung G, Roepstorff P, Sollid LM (2002) Celiac lesion $\mathrm{T}$ cells recognize epitopes that cluster in regions of gliadins rich in proline residues. Gastroenterology 123:803-809

Atchison J, Head L, Gates A (2010) Wheat as food, wheat as industrial substance; comparative geographies of transformation and mobility. Geoforum 41:236-246

Branlard G, Dardevet M, Saccomano R, Lagoutte F, Gourdon J (2001) Genetic diversity of wheat storage proteins and bread wheat quality. Euphytica 119:59-67

Camarca A, Anderson RP, Mamone G, Fierro O, Facchiano A, Costantini S, Zanzi D, Sidney J, Auricchio S, Sette A, Troncone R, Gianfrani C (2009) Intestinal T cell responses to gluten peptides are largely heterogeneous: implications for a peptide-based therapy in celiac disease. J Immunol 182:4158-4166

Cordewener JHG, Hause G, Görgen E, Busink R, Hause B, Dons HJM, Van Lammeren AAM, Van Lookeren Campagne MM, Pechan P (1995) Changes in synthesis and localization of members of the $70-\mathrm{kDa}$ class of heat-shock proteins accompany the induction of embryogenesis in Brassica napus L. microspores. Planta 196:747-755

Cummins AG, Roberts-Thomson IC (2009) Prevalence of celiac disease in the Asia-Pacific region. J Gastroen Hepatol 24:1347-1351 
Damania AB, Porceddu E, Jackson MT (1983) A rapid method for the evaluation of variation in germplasm collections of cereals using polyacrylamide gel electrophoresis. Euphytica 32:877-883

Day L, Augustin MA, Batey IL, Wrigley CW (2006) Wheat-gluten uses and industry needs. Trends Food Sci Technol 17:82-90

Denery-Papini S, Nicolas Y, Popineau Y (1999) Efficiency and limitations of immunochemical assays for the testing of gluten-free foods. J Cereal Sci 30:121-131

DuPont FM, Vensel WH, Chan R, Kasarda DD (2000) Characterization of the 1B-Type $\omega$-Gliadins from Triticum aestivum Cultivar Butte. Cereal Chem 77:607-614

Ensari A, Marsh MN, Moriarty KJ, Moore CM, Fido RJ, Tatham AS (1998) Studies in vivo of omega-gliadins in gluten sensitivity (coeliac sprue disease). Clin Sci 95:419-424

Fasano A (2006) Systemic autoimmune disorders in celiac disease. Curr Opin Gastroenterol 22:674-679

Gupta RB, MacRitchie F (1994) Allelic variation at glutenin subunit and gliadin loci, Glu-1, Glu-3 and Gli-1 of common wheats. II. Biochemical basis of the allelic effects on dough properties. J Cereal Sci 19:19-29

Gupta PK, Mir RR, Mohan A, Kumar J (2008) Wheat genomics: present status and future prospects. Int J Plant Genomics 2008:896451

Hassani ME, Shariflou MR, Gianibelli MC, Sharp PJ (2008) Characterisation of a $\omega$-gliadin gene in Triticum tauschii. J Cereal Sci 47:59-67

Hausch F, Shan L, Santiago NA, Gray GM, Khosla C (2002) Intestinal digestive resistance of immunodominant gliadin peptides. Am J Physiol Gastrointest Liver Physiol 283:G996-G1003

Hlywiak KH (2008) Hidden sources of gluten. Pract Gastroenterol 32:27-39

Ivarsson A, Persson LA, Nystrom L, Ascher H, Cavell B, Danielsson L, Dannaeus A, Lindberg T, Lindquist B, Stenhammar L, Hernell O (2000) Epidemic of coeliac disease in Swedish children. Acta Paediatr 89:165-171

Jackson EA, Morel MH, Sontag-Strohm T, Branlard G, Metakovsky EV, Redaelli R (1996) Proposal for combining the classification systems of alleles of Gli-1 and Glu-3 loci in bread wheat (Triticum aestivum L.). J Genet Breed 50:321-336

Janatuinen EK, Kemppainen TA, Julkunen RJK, Kosma VM, Maki M, Heikkinen M, Uusitupa MIJ (2002) No harm from five year ingestion of oats in coeliac disease. Gut 50:332-335

Kasarda DD, Autran J-C, Lew EJL, Nimmo CC, Shewry PR (1983) $\mathrm{N}$-terminal amino acid sequences of $\omega$-gliadins and $\omega$-secalins: implications for the evolution of prolamin genes. BBA Protein Struct M 747:138-150

Koning F (2008) Celiac disease: across the threshold of tolerance. In: Fasano A, Troncone R, Branski D (eds) Frontiers in celiac disease. Karger, Basel, pp 82-88

Laemmli UK (1970) Cleavage of structural proteins during the assembly of the head of bacteriophage T4. Nature 227:680-685

Leišová L, Kučera L, Dotlačil L (2007) Microsatellites as a tool to evaluate and characterise bread wheat core collection. In: Buck HT, Nisi JE, Salamón N (eds) Wheat production in stressed environments. Springer, The Netherlands, pp 771-778

Lohi S, Mustalahti K, Kaukinen K, Laurila K, Collin P, Rissanen H, Lohi O, Bravi E, Gasparin M, Reunanen A, Mäki M (2007) Increasing prevalence of coeliac disease over time. Aliment Pharmacol Ther 26:1217-1225

Maiuri L, Ciacci C, Ricciardelli I, Vacca L, Raia V, Auricchio S, Picard J, Osman M, Quaratino S, Londei M (2003) Association between innate response to gliadin and activation of pathogenic $\mathrm{T}$ cells in coeliac disease. Lancet 362:30-37

Maltin V, Charabaty A, Mangione R (2009) Medications: a hidden source of gluten. Pract Gastroenterol 33:32-36+38

Marti T, Molberg Ø, Li Q, Gray GM, Khosla C, Sollid LM (2005) Prolyl endopeptidase-mediated destruction of $\mathrm{T}$ cell epitopes in whole gluten: chemical and immunological characterization. J Pharmacol Exp Ther 312:19-26

Mitea C, Havenaar R, Drijfhout JW, Edens L, Dekking L, Koning F (2008a) Efficient degradation of gluten by a prolyl endoprotease in a gastrointestinal model: implications for coeliac disease. Gut $57: 25-32$

Mitea C, Kooy-Winkelaar Y, van Veelen P, de Ru A, Drijfhout JW, Koning F, Dekking L (2008b) Fine specificity of monoclonal antibodies against celiac disease-inducing peptides in the gluteome. Am J Clin Nutr 88:1057-1066

Molberg $\varnothing$, Flæte NS, Jensen T, Lundin KEA, Arentz-Hansen H, Anderson OD, Kjersti Uhlen A, Sollid LM (2003) Intestinal T-cell responses to high-molecular-weight glutenins in celiac disease. Gastroenterology 125:337-344

Molberg Ø, Uhlen AK, Jensen T, Flæte NS, Fleckenstein B, ArentzHansen H, Raki M, Lundin KEA, Sollid LM (2005) Mapping of gluten T-cell epitopes in the bread wheat ancestors: implications for celiac disease. Gastroenterology 128:393-401

Payne PI (1987) Genetics of wheat storage proteins and the effect of allelic variation on bread-making quality. Annu Rev Plant Physiol $38: 141-153$

Payne PI, Corfield KG, Holt LM, Blackman JA (1981a) Correlations between the inheritance of certain high-molecular weight subunits of glutenin and bread-making quality in progenies of six crosses of bread wheat. J Sci Food Agric 32:51-60

Payne PI, Holt LM, Law CN (1981b) Structural and genetic-studies on the high-molecular-weight subunits of wheat glutenin. 1. Allelic variation in subunits amongst varieties of wheat (Triticum aestivum). Theor Appl Genet 60:229-236

Qiao S-W, Bergseng E, Molberg Ø, Jung G, Fleckenstein B, Sollid LM (2005) Refining the rules of gliadin T cell epitope binding to the disease-associated DQ2 molecule in celiac disease: importance of proline spacing and glutamine deamidation. J Immunol 175:254 261

Rubio-Tapia A, Kyle RA, Kaplan EL, Johnson DR, Page W, Erdtmann F, Brantner TL, Kim WR, Phelps TK, Lahr BD, Zinsmeister AR, Melton LJ III et al (2009) Increased prevalence and mortality in undiagnosed celiac disease. Gastroenterology 137:88-93

Salentijn EMJ, Goryunova S, Bas N, van der Meer IM, van den Broeck HC, Bastien T, Gilissen LJWJ, Smulders MJM (2009) Tetraploid and hexaploid wheat varieties reveal large differences in expression of alpha-gliadins from homoeologous Gli-2 loci. BMC Genom 10:48

Schuppan D, Esslinger B, Dieterich W (2003) Innate immunity and coeliac disease. Lancet 362:3-4

Shan L, Molberg Ø, Parrot I, Hausch F, Filiz F, Gray GM, Sollid LM, Khosla C (2002) Structural basis for gluten intolerance in celiac sprue. Science 297:2275-2279

Shan L, Marti T, Sollid LM, Gray GM, Khosla C (2004) Comparative biochemical analysis of three bacterial prolyl endopeptidases: implications for coeliac sprue. Biochem J 383:311-318

Shan L, Qiao SW, Arentz-Hansen H, Molberg Ø, Gray GM, Sollid LM, Khosla C (2005) Identification and analysis of multivalent proteolytically resistant peptides from gluten: implications for celiac sprue. J Proteome Res 4:1732-1741

Shewry PR, Tatham AS (1997) Biotechnology of wheat quality. J Sci Food Agric 73:397-406

Shewry PR, Tatham AS (1999) The characteristics, structures and evolutionary relationships of prolamins. In: Shewry PR, Casey R (eds) Seed proteins. Kluwer Academic Publishers, Dordrecht, The Netherlands, pp 11-36

Sjöström H, Lundin KEA, Molberg Ø, Körner R, Mcadam SN, Anthonsen D, Quarsten H, Norén O, Roepstorff P, Thorsby E, Sollid LM (1998) Identification of a gliadin T-cell epitope in coeliac disease: general importance of gliadin deamidation for intestinal T-cell recognition. Scand J Immunol 48:111-115 
Spaenij-Dekking EHA, Kooy-Winkelaar EMC, Nieuwenhuizen WF, Drijfhout JW, Koning F (2004) A novel and sensitive method for the detection of $\mathrm{T}$ cell stimulatory epitopes of $\alpha / \beta$ - and $\gamma$-gliadin. Gut 53:1267-1273

Spaenij-Dekking L, Kooy-Winkelaar Y, van Veelen P, Drijfhout JW, Jonker H, van Soest L, Smulders MJM, Bosch D, Gilissen LJWJ, Koning F (2005) Natural variation in toxicity of wheat: potential for selection of nontoxic varieties for celiac disease patients. Gastroenterology 129:797-806

Stepniak D, Wiesner M, de Ru AH, Moustakas AK, Drijfhout JW, Papadopoulos GK, van Veelen PA, Koning F (2008) Large-scale characterization of natural ligands explains the unique glutenbinding properties of HLA-DQ2. J Immunol 180:3268-3278

Vader W, Kooy Y, van Veelen P, de Ru A, Harris D, Benckhuijsen W, Peña S, Mearin L, Drijfhout JW, Koning F (2002) The gluten response in children with celiac disease is directed toward multiple gliadin and glutenin peptides. Gastroenterology 122:1729-1737

Vader W, Stepniak DT, Bunnik EM, Kooy YMC, de Haan W, Drijfhout JW, van Veelen PA, Koning F (2003) Characterization of cereal toxicity for celiac disease patients based on protein homology in grains. Gastroenterology 125:1105-1113

Van de Wouw M, van Hintum T, Kik C, van Treuren R, Visser B (2010) Genetic diversity trends in twentieth century crop cultivars: a meta analysis. Theor Appl Genet 120:1241-1252

Van den Broeck HC, America AHP, Smulders MJM, Bosch D, Hamer RJ, Gilissen LJWJ, van der Meer IM (2009a) A modified extrac- tion protocol enables detection and quantification of celiac disease-related gluten proteins from wheat. J Chromatogr B 877:975-982

Van den Broeck HC, van Herpen TJWM, Schuit C, Salentijn EMJ, Dekking L, Bosch D, Hamer RJ, Smulders MJM, Gilissen LJWJ, van der Meer IM (2009b) Removing celiac disease-related gluten proteins from bread wheat while retaining technological properties: a study with Chinese Spring deletion lines. BMC Plant Biol 9:41

Van Esse HP, van 't Klooster JW, Bolton MD, Yadeta KA, van Baarlen P, Boeren S, Vervoort J, de Wit PJGM, Thomma BPHJ (2008) The Cladosporium fulvum virulence protein Avr2 inhibits host proteases required for basal defense. Plant Cell 20:1948-1963

Van Herpen TWJM, Goryunova S, van der Schoot J, Mitreva M, Salentijn EMJ, Vorst O, Schenk M, van Veelen P, Koning F, van Soest L, Vosman B, Bosch D et al (2006) Alpha-gliadin genes from the A, B, and D genomes of wheat contain different sets of celiac disease epitopes. BMC Genom 7:1

Ventura A, Magazzù G, Greco L (1999) Duration of exposure to gluten and risk for autoimmune disorders in patients with celiac disease. Gastroenterology 117:297-303

Woychik JH, Boundy JA, Dimler RJ (1961) Starch gel electrophoresis of wheat gluten proteins with concentrated urea. Arch Biochem Biophys 94:477-482

Zeven AC (2000) Traditional maintenance breeding of landraces. 1. Data by crop. Euphytica 116:65-85 